\title{
Change in Compressive Strength of Amalgams by Corrosion
}

\author{
Yoshio Kozono \\ Department of Materials Science (Chief : Prof. Ichiro Hayashi) \\ Kyushu Dental College, Kitakyushu, Japan \\ B. Keith Moore, Marjorie L. Swartz and Ralph W. Phillips \\ Department of Dental Materials (Chief : Prof. Ralph W. Phillips) \\ Indiana University School of Dentistry \\ Indianapolis, Indiana, U.S.A.
}

\section{Introduction}

It has been demonstrated by Phillips, et al. (1954) ${ }^{11}$ and Eames, et al. (1973) ${ }^{2}$ ) that the compressive strength of amalgam might be slightly increasing in air at room temperature even at the end of a six-month period, while it was deleteriously affectcd by moisture contamination. Patel, et al. (1979) ${ }^{3)}$ also found that the ageing of specimen in air at $37^{\circ} \mathrm{C}$ for four months had no effects on the compressive strength of several commercial high-copper type amalgams.

On the other hand, it has been evidenced through experimental and clinical studies $4 \sim 6)$ that the high-copper type amalgams were superior in mechanical properties to the conventional type ones. Better corrosion resistance of a high-copper amalgam, Dispersalloy, was also claimed through the clinical evaluation by Duperon, et al. (1971) ${ }^{7}$ and the test of the polarization resistance by Sarkar, et al. (1975) ${ }^{8)}$. The authors $\left.(1981)^{9}, 10\right)$ showed in a series of studies on in vitro corrosion of amalgam that the conventional lathe cut and spherical amalgams were severely attacked by saline solution to yield extreme corrosion products and microstructure disturbance. The highcopper amalgams generally did not exhibit so marked changes in appearance as the conventional ones. However, they released much larger amounts of $\mathrm{Cu}$ and $\mathrm{Hg}$ in saline solution at the later stage of a six-month period than the conventional ones. Espevik $(1977)^{11}$ ) also reported previously that Dispersalloy exhibited larger Cu dissolution in artificial saliva than other conventional and high-copper amalgams.

The present study was scheduled to determine the effects of ageing in corrosive solution on the compressive strength of various types of amalgams in relation to their different corrosion behaviors.

\section{Materials and Methods}

Eleven amalgam alloys of different types and systems were selected as listed in Table 1. Alloys D, D*, E and $\mathrm{I}^{*}$ are high-copper type amalgams. The mercuryalloy ratios and trituration conditions used followed the manufacturer's directions. Specimens $4 \mathrm{~mm}$ in diameter and $8 \mathrm{~mm}$ in length were prepared with a mechanical 
Table 1

Amalgam alloys tested

\begin{tabular}{|c|c|c|c|}
\hline & Alloy & Code & Manufacturer \\
\hline \multirow{4}{*}{ Lathe cut $\mathrm{Ag}-\mathrm{Sn}$} & Micro Alloy & M & L. D. Caulk, Milford, DE, U.S.A. \\
\hline & Micro Alloy* & $M^{*}$ & L. D. Caulk, Milford, DE, U.S.A. \\
\hline & Velvalloy & $\mathrm{V}$ & S. S. White, Philadelphia, PA, U.S.A. \\
\hline & Velvalloy* & $\mathrm{V}^{*}$ & S. S. White, Philadelphia, PA, U.S.A. \\
\hline \multirow{3}{*}{ Spherical Ag-Sn } & Spheraloy & $\mathrm{S}$ & Kerr Mfg., Romulus, MI, U.S.A. \\
\hline & Spher-A-Caps* & $\mathrm{S} *$ & Kerr Mfg., Romulus, MI, U.S.A. \\
\hline & Shofu Spherical* & $\mathrm{Ss}^{*}$ & Shofu Dental Mfg., Kyoto, Japan \\
\hline \multirow{3}{*}{$\begin{array}{l}\text { Lathe cut } \mathrm{Ag}-\mathrm{Sn} \text { admixed } \\
\text { with spherical }(\mathrm{Ag}-\mathrm{Cu})\end{array}$} & Dispersalloy & $\mathrm{D}$ & Johnson \& Johnson, East Windsor, NJ, U.S.A. \\
\hline & Dispersalloy* & $\mathrm{D}^{*}$ & Johnson \& Johnson, East Windsor, NJ, U.S.A. \\
\hline & Ease & $\mathrm{E}$ & L. D. Caulk, Milford, DE, U.S.A. \\
\hline Spherical (Ag-Sn-Cu) & Indiloy** & $I *$ & Shofu Dental Mfg., Kyoto, Japan \\
\hline
\end{tabular}

*contains no $\mathrm{Zn} \quad * *$ contains In

Table 2 Storage of amalgam specimens prior to compression test

\begin{tabular}{|c|c|}
\hline Storage & Code \\
\hline in air at $37^{\circ} \mathrm{C}$ for 1 week & $1 w A$ \\
\hline in distilled water at $37^{\circ} \mathrm{C}$ for 1 week & $1 w W$ \\
\hline in $0.5 \%$ sodium chloride solution at $37^{\circ} \mathrm{C}$ for 1 week & $1 w S$ \\
\hline in distilled water at $37^{\circ} \mathrm{C}$ for 3 months & $3 m W$ \\
\hline in $0.5 \%$ sodium chloride solution at $37^{\circ} \mathrm{C}$ for 3 months & $3 m S$ \\
\hline in distilled water at $37^{\circ} \mathrm{C}$ for 6 months & $6 m W$ \\
\hline in $0.5 \%$ sodium chloride solution at $37^{\circ} \mathrm{C}$ for 6 months & $6 m S$ \\
\hline
\end{tabular}

dynamic condensor. Prior to compression test, each specimen was suspended using a small basket in $50 \mathrm{ml}$ of distilled water or 0.5 per cent sodium chloride solution for various periods as shown in Table 2. The water or the saline solution was replaced with fresh one every month. Compression tests were conducted with a universal testing machine at a loading speed of $0.25 \mathrm{~mm} / \mathrm{min}$. Three specimens were prepared for each test. Another three specimens were tested after having been stored in air at $37^{\circ} \mathrm{C}$ for one week as the standards.

\section{Results}

Figure 1 shows the compressive strength of amalgams after each storage. Average percent changes in strength as compared with the standard strength obtained from one-week specimens in air are summarized in Table 3. Analysis of variance revealed that the changes in compressive strength differed significantly by the types of alloys and storage conditions as well as the interaction of these factors. Table 4 is the list of the alloys in which the significant difference in compressive strength appeared between each two storage conditions by t-test. In most of the amalgams tested, no 

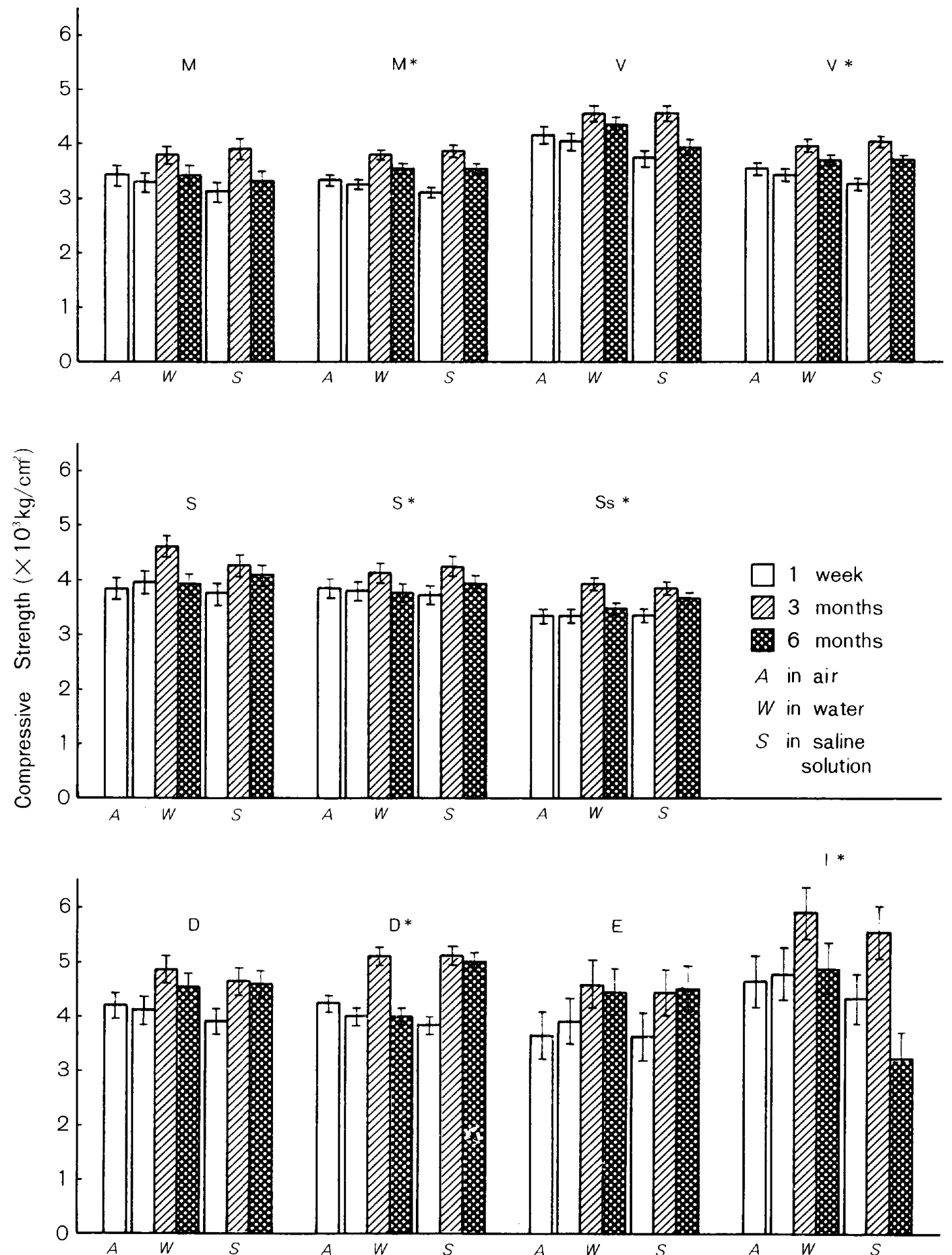

Fig. 1 Compressive strength of amalgams 
Table 3 Percent changes in compressive strength as compared with the specimen stored in air for one week

$(\%)$

\begin{tabular}{lrrrrrrrr}
\hline & $1 w A$ & $1 w W$ & $1 w S$ & $3 m W$ & $3 m S$ & $6 m W$ & $6 m S$ \\
\hline$M^{*}$ & 0.0 & -4.0 & -9.2 & 10.9 & 14.8 & -0.3 & -3.2 \\
$\mathrm{M}^{*}$ & 0.0 & -2.5 & -7.3 & 14.5 & 16.2 & 6.3 & 6.0 \\
$\mathrm{~V}^{*}$ & 0.0 & -3.6 & -10.2 & 8.9 & 9.7 & 3.8 & -5.9 \\
$\mathrm{~V}^{*}$ & 0.0 & -3.8 & -8.2 & 11.1 & 13.6 & 3.7 & 3.7 \\
$\mathrm{~S}^{*}$ & 0.0 & 1.6 & -2.7 & 19.1 & 10.6 & 1.5 & 5.9 \\
$\mathrm{~S}^{*}$ & 0.0 & -1.5 & -3.2 & 7.6 & 9.7 & -2.8 & 1.7 \\
$\mathrm{Ss}^{*}$ & 0.0 & -0.3 & 0.0 & 16.9 & 15.3 & 3.8 & 10.0 \\
$\mathrm{D}^{*}$ & 0.0 & -2.5 & -7.1 & 15.9 & 11.0 & 7.6 & 9.4 \\
$\mathrm{D}^{*}$ & 0.0 & -6.1 & -9.9 & 20.4 & 20.0 & -6.1 & 17.5 \\
$\mathrm{E}$ & 0.0 & 6.4 & -1.5 & 24.9 & 21.0 & 21.1 & 22.6 \\
$\mathrm{I}^{*}$ & 0.0 & 2.3 & -7.2 & 26.9 & 18.9 & 4.6 & -30.9 \\
\hline
\end{tabular}

Table 4 Alloys which exhibited significant difference in compressive strength between each two storage conditions by analysis of variance and $t$-test

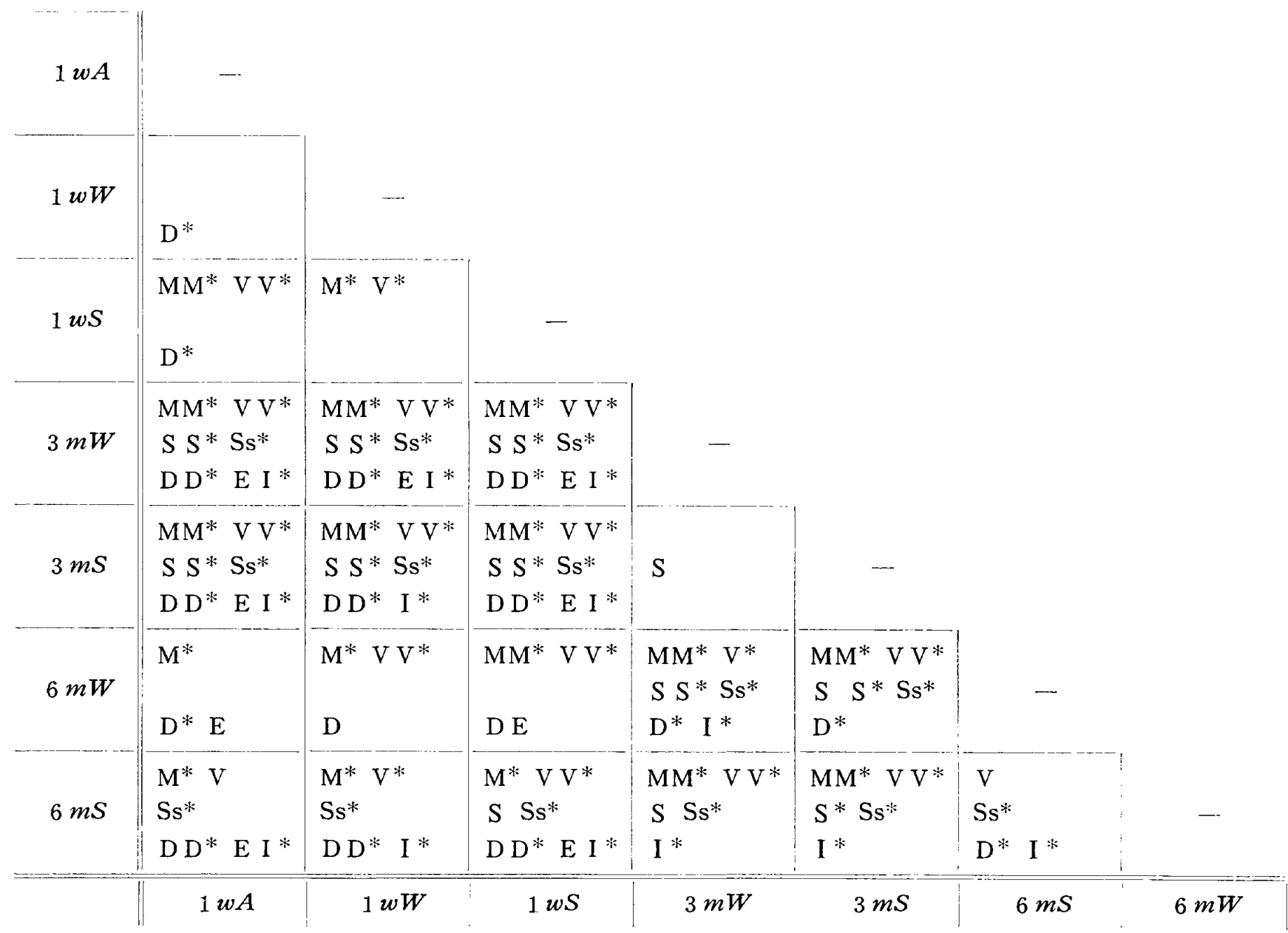


differences were statistically found in strength bctween one-week specimens in water and in air. Saline solution, on the contrary, weakned the amalgams in one week, and significant decrease in strength was observed in all of the conventional lathe cut alloys and one high-copper alloy $\mathrm{D}^{*}$. Three-month specimens both in water and in saline solution exhibited much higher compressive strength than one-week specimens. The increment of the strength was generally larger in the high-copper amalgams than in the conventional ones. There were no differences in strength between the specimens stored in water or in saline solution for three months except for alloy S.

Continued immersion of the specimen in the water or the saline solution over a sixmonth period resulted in decreased compressive strength. Especially amalgam I* showed a drastic decrease in strength to the minimum value of all in the saline solution after six months, although it was the strongest under any other storage conditions. High-copper amalgams $D$ and $E$ showed no significant differences between the threemonth specimens and the six-month ones.

\section{Discussion}

Compressive strength of cmalgam specimen after one week storage in air varied with the type of amalgam. In general the high-copper type amalgams showed the highest strength, followed by the conventional type spherical ones and the conventional lathe cut ones. The compressive strength was not changed statistically by storing the specimen in distilled water for one week in most of the amalgams tested. On the contrary, saline solution causid a considerable decrease in compressive strength of amalgam during one week period. Statistically significant decreases appeared in all the conventional lathe cut amalgams $\mathrm{M}, \mathrm{M}^{*}, \mathrm{~V}$ and $\mathrm{V}^{*}$, and one high-copper amalgam $D^{*}$. However, there could be observed no detectable microstructure changes nor corrosion products in these amalgams in such a short period. Phillips, et al. ${ }^{1}$ introduced the effect of the moisture ccntamination that decreased the compressive strength of $\mathrm{Zn}$ containing amalgam when the specimen was contaminated with saline solution for 30 seconds after trituration. Eames, et al. ${ }^{2}$ also showed the rapid decrease in strength of both $\mathrm{Zn}$ containing and $\mathrm{Zn}$ frec amalgams by contaminating them with saliva during condensation. The immersion of the specimen in the saline solution might have some effect of such contamination on the strength of amalgam. In any way the conventional lathe cut amalgams may be susceptible to the corrosive attack at the initial stages of setting so far as the compressive strength is concerned.

It has been demonstrated that the compressive strength of amalgam may be slightly increasing in air even at the end of a six-month period.1,2) In this experiment, however, all the amalgams exhibited a common tendency that the compressive strength of the three-month specimen was higher than that of the one-week specimen or the six-month one both in distilled water and in saline solution. The authors reported that the corrosion of amalgam in the saline solution was lowered with time up to 
around the third month and then activated markedly. ${ }^{9}$ Especially in the conventional amalgams, dramatic corrosion products and microstructure changes could be observed. 10) It might be referred to the prominent corrosion of amalgam that the highly significant decrease in strength was found in the conventional amalgams during the period from the fourth to sixth month. Although dissolution of the amalgam into the distilled water was very small even at the later stage of immersion ${ }^{9)}$, the water appeared to give a deleterious effect on the compressive strength as severely as the saline solution did.

It was shown by Youdelis $(1979)^{12,13}$ that the addition of In powder to amalgam alloy significantly increased one-hour and 24-hour compressive strength with In content up to 10 per cent. The original alloy particles of the high-copper amalgam I* are composed of $\mathrm{Ag}-\mathrm{Sn}-\mathrm{Cu}$ ternary system and include a small amount of In. I* was stronger than any other amalgams also in one-week or three-month storage, but it was markedly deteriorated to show the minimum strength of all by six-month immersion in the saline solution. Extremely large amounts of $\mathrm{Cu}$ and $\mathrm{Hg}$ were released from this amalgam specimen into the solution during a three-month period from the fourth to sixth month ${ }^{9)}$, resulting in marked microstructure changes and corrosion products ${ }^{10)}$. A sharp reduction of the strength of this amalgam after six-month immersion in the saline solution would be associated with such changes in composition and severely disturbed microstructure. It could not be assured whether these singular phenomena were due to the very fact that the original alloy is a ternary system or that the element In is present.

High-copper amalgams except $I^{*}$, on the contrary, maintained considerable strength over a six-month period in the saline solution. In amalgam $\mathrm{E}$, rather a small increase was observed in the strength. These amalgams appeared to be less influenced by the immersion in the saline solution than the conventional lathe cut amalgams as to the compressive strength. It could be supported by the fact that relatively sound microstructures were observed in these high-copper amalgams even after six-month immersion in the saline solution ${ }^{10)}$. Conventional spherical amalgams showed tendencies in strength something similar to the high-copper ones, even though not a small amount of corrosion products and microstructure changes were recognized.

Compressive strength of $\mathrm{Zn}$ containing alloy was not so different from that of $\mathrm{Zn}$ free alloy of the same brand, when they were stored in air for one week. However, one-week and six-month specimens of the former exhibited somewhat larger drops of the strength in the saline solution than in the distilled water as compared with those of the latter. It is considered that the $\mathrm{Zn}$ containing alloys might be slightly more susceptible to the attack of the saline solution than the $\mathrm{Zn}$ free alloys in respect to the compressive strength.

\section{Summary}

Conventional lathe cut amalgams showed a significant decrease in compressive 
strength when stored in 0.5 per cent saline solution for one week. The compressive strength increased by three-month storage in distilled water or in saline solution for all of the amalgams tested. Then the significant decrease was found in the strength of all of the conventional lathe cut amalgams and some of the conventional spherical and high-copper type ones during the three-month period from the fourth to sixth month in water and saline solution. High-copper type amalgams seemed to be the most resistant to corrosive attack in respect to the compressive strength. Exceptionally a ternary system of high-copper amalgam containing In exhibited a marked reduction in strength by placing it in the saline solution for six months. $\mathrm{Zn}$ free alloys were slightly insensitive to the attack of the saline solution as compared with $\mathrm{Zn}$ containing alloys of the same brand.

\section{References}

1) Phillips, R. W., Swartz, M. L., et al.: Effect of moisture contamination on the compressive strength of amalgam, J. Amer. Dent. Ass. 49:436-438, 1954.

2) Eames, W. B., Tharp, L. G., et al. : The effects of saliva contamination on dental amalgam, J. Amer. Dent. Ass. $86: 652-656,1973$.

3) Patel, S. and Cruickshanks-Boyd, D. W.: The effect of ageing on the creep and compressive strength of high copper content amalgams, Brit. Dent. J. $147: 42^{--44,} 1979$.

4 Innes, D.B.K. and Youdelis, W. V.: Dispersion strengthened amalgams, J. Can. Dent. Ass. $29: 587-593,1963$.

5 Mahler, D. B., Terkla, L. G., et al.: Marginal fracture of amalgam restorations, J. Dent. Res. $52: 823-827,1973$.

6 Osborn, J. W., Phillips, R. W., et al. : Static creep of certain commercial amalgam alloys, J. Amer. Dent. Ass. $89: 620-622,1974$.

7) Duperon, D. F., Nevile, M. D., et al. : Clinical evaluation of corrosion resistance of conventional alloy, spherical-particle alloy, and dispersion-phase alloy, J. Pros. Dent. $25: 650^{--}$ 656,1971 .

8 ) Sarkar, N. K. and Greener, E. H. : In vitro chloride corrosion behavior of Dispersalloy, J. Oral Rehabil. $2: 139-144,1975$.

9) Kozono, Y., Moore, B. K., et al. : Dissolution of amalgam in saline solution, J. Biomed. Mater. Res. (In Press)

10) Kozono, Y., Hayashi, I., et al.: Change in microstructure of amalgams by corrosion, J. Kyushu Dent. Soc. $4: 489-501,1981$.

11) Espevik, S.: In vitro corrosion of deatal amalgams with different $\mathrm{Cu}$ content, Scand, J. Dent. Res. $85: 631-636,1977$.

12) Youdelis, W. V.: Effect of indium on residual mercury content and compressive strength of amalgam, J. Can. Dent. Ass. 2:60-62, 1979.

13) Youdelis, W. V.: Effect of indium on dispersion-type amalgam, J. Can. Dent. Ass. 2:64-66,1979 . 


\title{
アマルガム压縮強さの嗆食による変化
}

\author{
小園 凱 夫 \\ 九州曾科大学歯科理工学講座（主任：林一郎教授〉
}

\section{B. Keith Moore, Marjorie L. Swartz and Ralph W. Phillips \\ Department of Dental Materials (Chief : Prof. Ralph W. Phillips) \\ Indiana University School of Dentistry \\ Indianapolis, Indiana, U.S.A.}

各種アマルガムの死縮強さにおよぼす窝住の影響を調

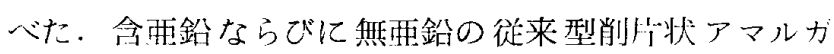
ム，球状アマルガム执よび高銅型アマルガム11種を用 い， $37^{\circ} \mathrm{C}$ 水中あるい恃 $0.5 \%$ 食圔水中に 1 週間， 3 力 月, 6 力月浸漬した後, 圧縮強さ在測定した. 水中に 1

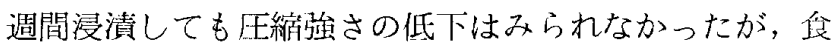
塩水体に浸漬すると，從来型削㸝アマルガムにおい て, 空父中に 1 週間保保した対照群に比して 7 〜 $10 \%$ の 低下が認められた。3 力月経過する上，水中，㿮塩水中 いずれにおいても使用したアマルガムすべてに压縮強さ の堌版みられた。 その後 6 力月目までの 3 力月間に強 さは低下したが，その成少睹はアマルガムのタイプによ
って異なっていた，従来型削牌状アマルガムが比較的大 きな低下を赤した。削片状 $r$ 合金に球状 $\mathrm{Ag}-\mathrm{Cu}$ 共晶合 金を加えた高銅型アマルガムには，食塩水中に打いても 有意な低下は認められなかった。压維強さに関する限 り，乙れらの合金は最も腐食の影響が少ない之いえる。 In を含屯 $\mathrm{Ag}-\mathrm{Sn}-\mathrm{Cu}$ 三元合金から成る高銅型アマル ガムは 3 カ月まで他のいずれてのアマルガムより高い生縮 強さを少したが，6力月経過すると強さは箸しく低下

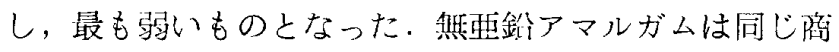
品名の含画鈴アマルガムに比して，わずかに食塩水の影 絑による強さの低下が少ないという傾向が認められた。 